\title{
Ascotricins A and B, novel antagonists of sphingosine- 1-phosphate receptor 1 from Ascotricha chartarum Berk. SANK 14186
}

\begin{abstract}
Kiyoaki Yonesu ${ }^{1}$, Takashi Ohnuki ${ }^{2}$, Yasunori Ono ${ }^{2}$, Toshio Takatsu ${ }^{2}$ and Futoshi Nara ${ }^{1}$
Ascotricins A and B were isolated as novel sphingosine-1-phosphate receptor $1\left(\mathrm{~S}_{1} \mathrm{P}_{1}\right)$ antagonists from a cultured broth of a fungus identified as Ascotricha chartarum Berk. SANK 14186. The two compounds were purified by solvent extraction, reversedphase (RP) column chromatography and a preparative RP-HPLC. The structures were determined by various NMR experiments and by LC/MS and GC/MS analyses. The $S 1 P_{1}$ antagonist activities were measured by a cyclic AMP assay using $S_{1} P_{1}$-expressing cells and the $\mathrm{IC}_{50}$ values were 8.2 and $1.8 \mu \mathrm{m}$, respectively. In a [33 P]sphingosine-1-phosphate/S1P $\mathrm{P}_{1}$-binding assay, those values were 120 and $39 \mu \mathrm{m}$, and in a migration assay using human umbilical vein endothelial cells (HUVECs), they were 94 and $28 \mu \mathrm{m}$, respectively. Thus, ascotricins $A$ and $B$ are novel $\mathbf{S}_{1} \mathbf{P}_{1}$ antagonists showing an inhibition activity toward HUVEC migration.
\end{abstract}

The Journal of Antibiotics (2009) 62, 359-364; doi:10.1038/ja.2009.40; published online 22 May 2009

Keywords: Ascotricha chartarum; ascotricins A and B; HUVEC; S1P 1 antagonist; sphingosine-1-phosphate

\section{INTRODUCTION}

Sphingosine-1-phosphate (Sph-1-P) is an intermediate in the sphingomyelin degradation pathway ${ }^{1}$ and is also a bioactive lipid messenger. Sph-1-P provokes a variety of cellular responses, including proliferation, prolongation of survival, cytoskeleton rearrangement, etc. ${ }^{2,3}$ The first breakthrough in Sph-1-P research was finding its receptor, the endothelial differentiation gene-1/Sphingosine-1-phosphate receptor 1 $\left(\text { Edg- } 1 / \mathrm{S}_{1} \mathrm{P}_{1}\right)^{4}$. Sph-1-P promoted proliferation, migration and tube formation of vascular endothelial cells through $\mathrm{S}_{1} \mathrm{P}_{1},{ }^{5-7}$ and the phenotype of $\mathrm{S}_{1} \mathrm{P}_{1}$ homozygous knockout mice strongly indicated that $\mathrm{S}_{1} \mathrm{P}_{1}$ was indispensable for angiogenesis. ${ }^{8,9}$ The second expansion of Sph-1-P research was re-finding $\mathrm{S}_{1} \mathrm{P}_{1}$ as a pharmacological target of a new immunosuppressant, FTY720 (Fingolimod). ${ }^{10,11}$ The active metabolite of FTY720 stimulated $\mathrm{S}_{1} \mathrm{P}_{1}$ as do other synthetic $\mathrm{S}_{1} \mathrm{P}_{1}$ agonists and caused lymphopenia and the resultant immunosuppression. ${ }^{10-12}$ Currently, FTY720 is in an ongoing developmental stage in clinical trials as a novel immunosuppressant for multiple sclerosis.

Although the current physiological research for Sph-1-P has shifted to $\mathrm{S}_{1} \mathrm{P}_{1}$ agonists and to lymphopenia, the relationship of $\mathrm{S}_{1} \mathrm{P}_{1}$ and angiogenesis has not yet been sufficiently studied. A few potent $\mathrm{S}_{1} \mathrm{P}_{1}$ antagonists have been discovered, ${ }^{13,14}$ but their capacity as angiogenesis inhibitors has not yet been examined. To obtain a functional S1P antagonist, we searched for one in microorganisms because several microorganisms have sphingolipid synthesis systems, and microbial secondary metabolites are thought to be attractive sources of Sph-1-P analogs.
In this study, we discovered ascotricins A (1) and B (2) (Figure 1) in a cultured broth of the strain, Ascotricha chartarum Berk. SANK 14186. Thus, the identification of the producing organism, the isolation, physico-chemical properties, structure elucidation and biological activities of ascotricins are described herein.

\section{RESULTS}

Identification of the producing organism

The producing microorganism, SANK 14186, shown in Figure 2, was isolated from a soil sample collected from Okinawa Prefecture, Japan.

Colonies on modified Weitzman and Silva-Hutner ${ }^{15}$ agar attained $27-33 \mathrm{~mm}$ in diameter by 14 days at $23^{\circ} \mathrm{C}$. They were floccose, consisting of short aerial mycelia and submerged vegetative hyphae, white at first, becoming dark green as they produced ascomata and conidiophores. Ascomata were superficial or sometimes immersed, dark brown to black, subglobose, ostiolate, $450-456 \mu \mathrm{m}$ in height and $330-350 \mu \mathrm{m}$ in diameter. The terminal hairs were erect, geniculate, often dichotomously branched, euseptate, dark brown to black and $3-4 \mu \mathrm{m}$ in diameter at the base; short sterile hyaline branches were at the geniculate nodes, clavate, $6.5-13.6 \mu \mathrm{m}$ in length and $2.8-4.0 \mu \mathrm{m}$ in diameter. The lateral hairs were similar to the terminal hairs. Asci were linear-cylindrical, thin walled, deliquescing after the spores have matured, 8 spored, $52-72 \mu \mathrm{m}$ in length and $5.8-7.8 \mu \mathrm{m}$ in diameter. The ascospores were uniseriate, dark brown to black when mature, discoid, with a single distinct equatorial slit and 7.4-9.2 $\mu \mathrm{m}$ in length and $5.9-8.3 \mu \mathrm{m}$ in width. The conidiophores were erect, arose from

${ }^{1}$ Exploratory Research Laboratories II, Daiichi Sankyo Co. Ltd., Kitakasai, Edogawa-ku, Tokyo, Japan and ²Exploratory Research Laboratories I, Daiichi Sankyo Co. Ltd., Hiromachi, Shinagawa-ku, Tokyo, Japan

Correspondence: K Yonesu, Exploratory Research Laboratories II, Daiichi Sankyo Co. Ltd., 1-16-13, Kitakasai, Edogawa-ku, Tokyo 134-8630, Japan.

E-mail: yonesu.kiyoaki.t8@daiichisankyo.co.jp

Received 11 March 2009; revised 4 April 2009; accepted 7 May 2009; published online 22 May 2009 
the basal mycelium or the terminal hairs, were olive brown to dark brown, becoming pale brown to hyaline toward the apex, euseptate, similar to the terminal hairs, simple or dichotomous and $2.2-4.0 \mu \mathrm{m}$ in diameter. Conidiogenous cells arose terminally from the branches, were pale brown, $5.6-12.8 \mu \mathrm{m}$ in length, $2.4-3.6 \mu \mathrm{m}$ in diameter and bore conidia-producing denticles. Conidia were produced sympodially from the denticles, were pale brown with age, irregularly globose, the walls conspicuously roughened with minute warts and were $4-7 \mu \mathrm{m}$ in diameter (Figure 2).

On the basis of these taxonomic properties, the strain, SANK 14186, was identified as A. chartarum Berk. ${ }^{16}$ This strain has been deposited at the International Patent Organism Depositary, National Institute of Advanced Industrial Science and Technology, Japan, under the accession no. FERM BP-08506.

\section{Fermentation}

One loopful of the culture of the strain, A. chartarum SANK 14186, on an agar slant was inoculated into $30 \mathrm{ml}$ of a sterilized seed medium consisting of glycerol $3 \%$, glucose $3 \%$, soluble starch $2 \%$, soybean meal $1 \%$, gelatin $0.25 \%$, yeast extract $0.25 \%$ and $\mathrm{NH}_{4} \mathrm{NO}_{3} 0.25 \%$ in a $100-\mathrm{ml}$ Erlenmeyer flask. The flask was incubated at $23^{\circ} \mathrm{C}$ on a rotary shaker at 210 r.p.m. for 5 days. The seed culture $(2 \mathrm{ml})$ was transferred into two 500-ml Erlenmeyer flasks containing $80 \mathrm{ml}$ of sterilized producing medium consisting of glycerol $5 \%$, fresh mashed potato $5 \%$, malt extract $0.5 \%$ and yeast extract $0.5 \%$, and incubated at $23{ }^{\circ} \mathrm{C}$ on a rotary shaker at 210 r.p.m. for 7 days.

\section{Isolation}

After the fermentation broth $(400 \mathrm{ml})$ was adjusted to $\mathrm{pH} 3$, the active substance was extracted from the broth with an equal volume of acetone and the mixture was filtered. The filtrate was extracted with

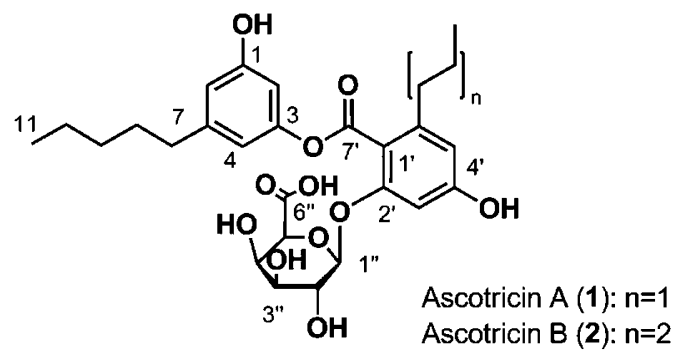

EtOAc $(400 \mathrm{ml})$ and then the organic layer was dried over anhydrous $\mathrm{Na}_{2} \mathrm{SO}_{4}$ and concentrated in vacuo to give crude oil $(900 \mathrm{mg})$. The crude oil was dissolved in $\mathrm{MeOH}$ and applied to a COSMOSIL 140C18-OPN column ( $25 \mathrm{ml}$, Nacalai Tesque Inc., Kyoto, Japan). The column was developed with acetonitrile-water containing $0.05 \%$ formic acid and the active substance was eluted with $50 \%$ aqueous acetonitrile containing $0.05 \%$ formic acid. The eluate was concentrated in vacuo to give a crude residue and further purified by preparative HPLC using a Develosil-packed column (Develosil C30UG-5, 20×150 mm, Nomura Chemical Co. Ltd., Seto, Japan), with $55 \%$ aqueous acetonitrile containing $0.05 \%$ formic acid as a mobile phase, with a flow rate of $11 \mathrm{ml} \mathrm{min}^{-1}$. Fractions containing compounds $\mathbf{1}$ and $\mathbf{2}$ were separately concentrated in vacuo and lyophilized to give compounds $\mathbf{1}(94.7 \mathrm{mg})$ and $2(51.9 \mathrm{mg})$ as colorless powders, respectively.

\section{Physico-chemical properties and structural elucidation}

The physico-chemical properties of compounds $\mathbf{1}$ and $\mathbf{2}$ are summarized in Table 1 . These data suggested that they are structurally related homologs. The molecular formula of compound 1 was determined to be $\mathrm{C}_{27} \mathrm{H}_{34} \mathrm{O}_{11}$ on the basis of HRFAB-MS and $1 \mathrm{H}$ and ${ }^{13} \mathrm{C}$ NMR

Table 1 Physico-chemical properties of ascotricin A (1) and B (2)

\begin{tabular}{|c|c|c|}
\hline & 1 & 2 \\
\hline Appearance & Colorless powder & Colorless powder \\
\hline $\begin{array}{l}\text { Molecular } \\
\text { formula }\end{array}$ & $\mathrm{C}_{27} \mathrm{H}_{34} \mathrm{O}_{11}$ & $\mathrm{C}_{29} \mathrm{H}_{38} \mathrm{O}_{11}$ \\
\hline \multicolumn{3}{|c|}{$H R-F A B-M S(m / z)$} \\
\hline Found & $579.1814[\mathrm{M}+2 \mathrm{Na}-\mathrm{H}]^{+}$ & $607.2132[\mathrm{M}+2 \mathrm{Na}-\mathrm{H}]^{+}$ \\
\hline Calcd & 579.182 & 607.213 \\
\hline$[\alpha]_{D}^{25}$ & $-21.7(\mathrm{MeOH}$, c 1.0) & $-18(\mathrm{MeOH}$, c 0.5) \\
\hline UV $\lambda_{\max }$ & $260 \mathrm{~nm}(\mathrm{MeOH}, \varepsilon$ 7800) & $261 \mathrm{~nm}(\mathrm{MeOH}, \varepsilon$ 9000) \\
\hline \multicolumn{3}{|l|}{ Solubility } \\
\hline Soluble & $\mathrm{MeOH}$, acetone & $\mathrm{MeOH}$, acetone \\
\hline Insoluble & $\mathrm{H}_{2} \mathrm{O}, n$-hexane & $\mathrm{H}_{2} \mathrm{O}, n$-hexane \\
\hline IR $v_{\max } \mathrm{cm}^{-1}$ & $\begin{array}{l}3377,2958,2930,2872 \\
1726,1612,1590\end{array}$ & $\begin{array}{l}3376,2956,2929,2871 \\
2860,1726,1615\end{array}$ \\
\hline
\end{tabular}

Figure 1 Structures of ascotricins A (1) and B (2).

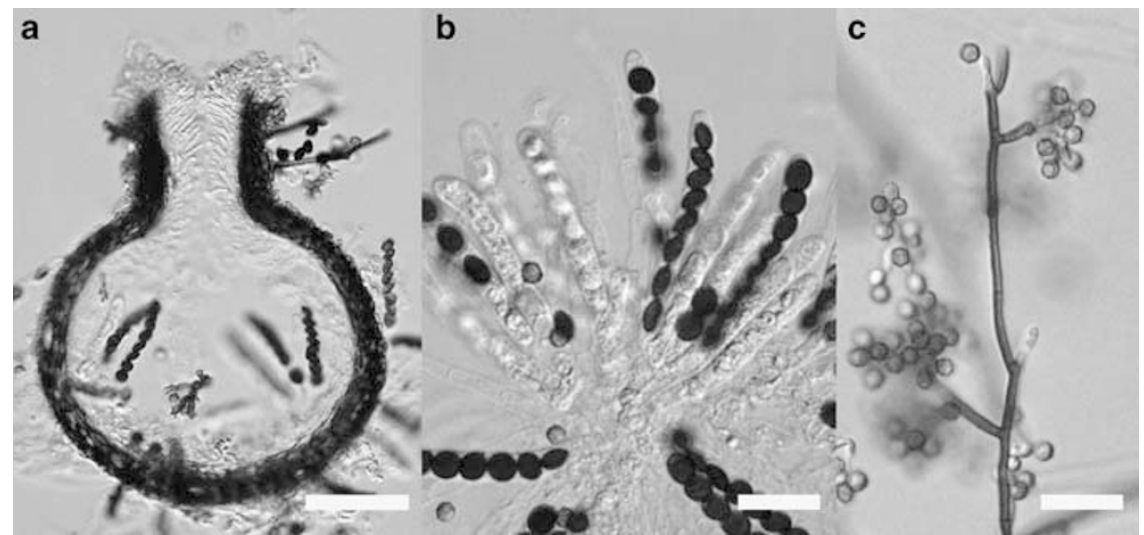

Figure 2 A. chartarum Berk. SANK 14186. (a) Ascoma; (b) Paraphyses and asci with ascospores; (c) Conidiophores and conidia. Scales: $a=50 \mu \mathrm{m}$, $b, c=20 \mu \mathrm{m}$. 
Table $2{ }^{1} \mathrm{H}$ and ${ }^{13} \mathrm{C}$ NMR spectral data of ascotricin A (1) and B (2)

\begin{tabular}{|c|c|c|c|c|c|c|c|c|}
\hline \multirow[b]{2}{*}{ Position } & \multicolumn{4}{|c|}{1} & \multicolumn{4}{|c|}{2} \\
\hline & $\delta_{c}^{a}$ & mult. & $\delta_{H}^{b}$ & mult.(J Hz) & $\delta_{c}{ }^{a}$ & mult. & $\delta_{H}^{b}$ & mult.(J Hz) \\
\hline 1 & 158.2 & $\mathrm{~s}$ & & & 158.0 & $s$ & & \\
\hline 2 & 106.7 & d & 6.48 & $1 \mathrm{H}, \mathrm{m}$ & 106.6 & d & 6.50 & $1 \mathrm{H}, \mathrm{m}$ \\
\hline 3 & 151.5 & $\mathrm{~s}$ & & & 151.4 & $t \mathrm{~s}$ & & \\
\hline 4 & 112.1 & d & 6.35 & $1 \mathrm{H}, \mathrm{m}$ & 112.1 & $d$ & 6.45 & $1 \mathrm{H}, \mathrm{m}$ \\
\hline 5 & 144.5 & $\mathrm{~s}$ & & & 144.6 & $5 \mathrm{~s}$ & & \\
\hline 6 & 112.7 & $d$ & 6.39 & $1 \mathrm{H}, \mathrm{m}$ & 112.7 & $7 \mathrm{~d}$ & 6.47 & $1 \mathrm{H}, \mathrm{m}$ \\
\hline 7 & 35.0 & $\mathrm{t}$ & 2.44 & $2 \mathrm{H}, \mathrm{m}$ & 35.0 & $t$ & 2.56 & $\mathrm{~m}, \mathrm{o}$ \\
\hline 8 & 30.3 & t & 1.44 & $2 \mathrm{H}, \mathrm{m}$ & 30.2 & $t$ & 1.54 & $\mathrm{~m}, \mathrm{o}$ \\
\hline 9 & 30.9 & $t$ & 1.15 & $2 \mathrm{H}, \mathrm{m}$ & 30.8 & $3 t$ & 1.55 & $\mathrm{~m}, \mathrm{o}$ \\
\hline 10 & 22.0 & $\mathrm{t}$ & 1.21 & $2 \mathrm{H}, \mathrm{m}$ & 21.9 & $\Rightarrow \mathrm{t}$ & 1.28 & $\mathrm{~m}, \mathrm{o}$ \\
\hline 11 & 14.0 & $q$ & 0.76 & $3 \mathrm{H}, \mathrm{t}(7.1)$ & 13.9 & $q$ & 0.85 & $\mathrm{~m}, \mathrm{o}$ \\
\hline $1^{\prime}$ & 114.0 & $\mathrm{~s}$ & & & 113.9 & $\mathrm{~s}$ & & \\
\hline $2^{\prime}$ & 156.3 & $\mathrm{~s}$ & & & 156.0 & $\mathrm{~s}$ & & \\
\hline $3^{\prime}$ & 100.3 & d & 6.43 & $1 \mathrm{H}, \mathrm{d}(1.4)$ & 99.8 & d & 6.46 & $1 \mathrm{H}$, brs \\
\hline $4^{\prime}$ & 159.6 & $\mathrm{~s}$ & & & 159.5 & $\mathrm{~s}$ & & \\
\hline $5^{\prime}$ & 109.5 & d & 6.23 & $1 \mathrm{H}, \mathrm{d}(1.4)$ & 109.3 & $d$ & 6.34 & $1 \mathrm{H}$, brs \\
\hline $6^{\prime}$ & 141.8 & $\mathrm{~s}$ & & & 142.2 & $\mathrm{~s}$ & & \\
\hline $7^{\prime}$ & 166.1 & $\mathrm{~s}$ & & & 166.0 & $s$ & & \\
\hline $8^{\prime}$ & 34.9 & $\mathrm{t}$ & 2.41 & $2 \mathrm{H}, \mathrm{m}$ & 32.3 & $\mathrm{t}$ & 2.55 & $\mathrm{~m}, \mathrm{o}$ \\
\hline $9^{\prime}$ & 24.0 & $t$ & 1.48 & $2 \mathrm{H}, \mathrm{m}$ & 31.1 & $t$ & 1.55 & $\mathrm{~m}, \mathrm{o}$ \\
\hline $10^{\prime}$ & 13.8 & $q$ & 0.80 & $3 \mathrm{H}, \mathrm{t}(7.3)$ & 30.5 & t & 1.55 & $\mathrm{~m}, \mathrm{o}$ \\
\hline $11^{\prime}$ & & & & & 21.9 & $\mathrm{t}$ & 1.28 & $\mathrm{~m}, \mathrm{o}$ \\
\hline $12^{\prime}$ & & & & & 13.8 & $q$ & 0.84 & $\mathrm{~m}, \mathrm{o}$ \\
\hline $1^{\prime \prime}$ & 100.9 & $d$ & 4.74 & $1 \mathrm{H}, \mathrm{d}(7.6)$ & 100.0 & $d$ & 4.91 & $1 \mathrm{H}, \mathrm{d}(7.3)$ \\
\hline $2^{\prime \prime}$ & 70.1 & d & 3.49 & $1 \mathrm{H}, \mathrm{dd}(7.6,9.3)$ & 69.8 & d & 3.57 & $1 \mathrm{H}, \mathrm{dd}(7.3,9.5)$ \\
\hline $3^{\prime \prime}$ & 73.4 & $d$ & 3.34 & $1 \mathrm{H}, \mathrm{dd}(2.2,9.3)$ & 73.0 & $d$ & 3.52 & $1 \mathrm{H}, \mathrm{dd}(2.3,9.5)$ \\
\hline $4^{\prime \prime}$ & 69.8 & $d$ & 3.82 & $1 \mathrm{H}, \mathrm{dd}(0.7,2.2)$ & 69.7 & $d$ & 3.97 & $1 \mathrm{H}, \mathrm{dd}(0.6,2.3)$ \\
\hline $5^{\prime \prime}$ & 75.1 & $d$ & 3.95 & $1 \mathrm{H}, \mathrm{d}(0.7)$ & 73.8 & $d$ & 4.36 & $1 \mathrm{H}, \mathrm{d}(0.6)$ \\
\hline $6^{\prime \prime}$ & 170.7 & $\mathrm{~s}$ & & & 169.5 & $\mathrm{~s}$ & & \\
\hline
\end{tabular}

${ }^{a}$ Chemical shifts are shown with reference to DMSO- $d 6$ as $\delta_{H} 2.50$.

${ }^{b}$ Chemical shifts are shown with reference to DMSO- $d 6$ as $\delta_{\mathrm{C}} 39.5$. o: overlapped.

spectral data. The IR spectra of 1 suggested the presence of hydroxyl $\left(3377 \mathrm{~cm}^{-1}\right)$, alkyl $\left(2958\right.$ and $\left.2930 \mathrm{~cm}^{-1}\right)$ and ester or carboxylic acid groups $\left(1726 \mathrm{~cm}^{-1}\right)$. The ${ }^{1} \mathrm{H}$ and ${ }^{13} \mathrm{C}$ NMR spectral data are summarized in Table 2.

The ${ }^{1} \mathrm{H}$ NMR spectrum of compound $\mathbf{1}$ showed signals attributed to two methyl, six methylene, five methine and two sets of metacoupled aromatic protons. The ${ }^{13} \mathrm{C}$ NMR spectrum of compound 1 showed 27 resolved signals, which were classified into one ester carbonyl, one carboxyl, six methylene, five $O$-methine, five $s p^{2}$ methine, seven $s p^{2}$ quaternary and two methyl carbons by an analysis of the DEPT spectra. Twelve $s p^{2}$ carbon signals indicated the existence of two aromatic ring moieties. As shown in Figure 3, five methine carbons $\left(\delta_{c} 100.9,75.1,73.4,70.1\right.$ and 69.8$)$, substituted by hetero atoms, and a correlated carboxyl carbon $\left(\delta_{c}\right.$ 170.7) in the HMBC spectrum indicated the presence of uronic acid moiety. DQF COSY and HSQC-HOHAHA experiments of $\mathbf{1}$ showed the connectivity from $\mathrm{H}-7$ to $\mathrm{H}-11$, from $\mathrm{H}-8^{\prime}$ to $\mathrm{H}-10^{\prime}$ and from $\mathrm{H}-1^{\prime \prime}$ to $\mathrm{H}-5^{\prime \prime}$. From these results, the presence of 1,3,5-tri-substituted and 1,2,4,6-tetra-substituted benzen moieties was revealed, as well as one propyl, one pentyl and one uronic acid moiety.

Identification of the uronic acid moiety was performed by a GC/MS analysis of an acid hydrolysate of 1 . Compound 1 was treated with $6 \mathrm{~N}$

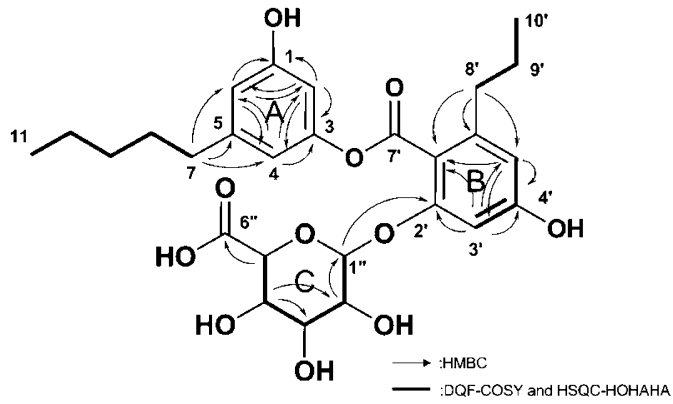

Figure 3 Significant correlations observed in the 2D NMR spectra of ascotricin $A(1)$.

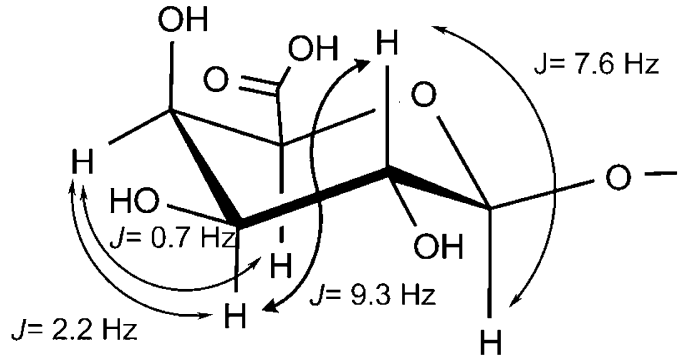

Figure 4 Stereochemistry of the galacturonic acid moiety of ascotricin A (1).

$\mathrm{HCl}$ for $8 \mathrm{~h}$ at $110^{\circ} \mathrm{C}$, and the resulting hydrolysate was converted into a TMS derivative by N,O-bis-(trimethylsilyl)trifluoroacetamide (BSTFA) and was then analyzed by GC/MS. The retention time of the TMS derivative was identical to that of the authentic galacturonic acid (derivative of $1,14.58 \mathrm{~min}$; authentic sample, $14.61 \mathrm{~min}$ ). The relative configuration at $\mathrm{C}-1^{\prime \prime}$ was elucidated to be $\beta$ by the coupling constants of $\mathrm{H}-1^{\prime \prime}\left(J_{1^{\prime \prime}, 2^{\prime \prime}}=7.6 \mathrm{~Hz}\right)$ as shown in Figure 4.

The structural elucidation of two aromatic ring moieties was achieved as follows. Of the four oxygenated aromatic carbons, two appeared relatively downfield at $\delta_{\mathrm{c}} 159.6$ and $\delta_{\mathrm{c}} 158.2$, respectively, which were assigned to C-1 and C- $4^{\prime}$ having free phenolic groups. The anomeric proton $\left(\mathrm{H}-1^{\prime \prime}, \delta_{\mathrm{H}} 4.74\right)$ of the uronic acid moiety was longrange coupled to $\mathrm{C}-2^{\prime}$ and it was thereby revealed that $\mathrm{C}-1^{\prime \prime}$ was linked to $\mathrm{C}-2^{\prime}$ on the aromatic ring $\mathrm{B}$ in Figure 3 . The signals for two methylene groups of the propyl and pentyl moieties at C-7 and C- $8^{\prime}$ were downfield shifted $\left(\delta_{c} 35.0\right.$ and 34.9$)$ and were suggested to be because of two sets of benzyl positions. In the HMBC spectrum of $\mathbf{1}$, the long-range couplings from H-7 to C-4, C-5 and to C-6 (Figure 3) revealed that the pentyl moiety was connected to $\mathrm{C}-5$. The observed HMBC correlations from $\mathrm{H}-2$ to C-1, C-3, C-4 and to C-6, from H-4 to C-2, C-3 and to C-6, and from H-6 to C-1, C-2 and C-4 established a 1,3-dioxy-5-pentylbenzen substitution for the aromatic ring $\mathrm{A}$ of the structure. The structure of aromatic ring B was revealed by similar HMBC experiments. The observed HMBC correlations from $\mathrm{H}-3^{\prime}$ to $\mathrm{C}-2^{\prime}, \mathrm{C}-4^{\prime}$ and $\mathrm{C}-5^{\prime}$, from $\mathrm{H}-5^{\prime}$ to $\mathrm{C}-3^{\prime}, \mathrm{C}-4^{\prime}$ and $\mathrm{C}-1^{\prime}$, and from $\mathrm{H}-8^{\prime}$ to $\mathrm{C}-1^{\prime}, \mathrm{C}-5^{\prime}$ and to $\mathrm{C}-6^{\prime}$ revealed that the propyl moieties were connected to C- $6^{\prime}$. The $s p^{2}$ quaternary carbon $\left(\mathrm{C}-1^{\prime}, \delta_{\mathrm{c}} 114.0\right)$ had no long-range correlation with any substituent directly linking to $\mathrm{C}-1^{\prime}$. However, considering the molecular formula, the remaining ester carbonyl carbon must be directly attached to C-1. From these results, a 2,3-dioxy-6-propyl-benzoate was determined as the aromatic ring $\mathrm{B}$ in the structure of 1 . The oxygenated $s p^{2}$ carbon, C-3 $\left(\delta_{\mathrm{c}} 151.5\right)$, must be esterified to form depside with $\mathrm{C}-7^{\prime}$. This assignment is consistent 


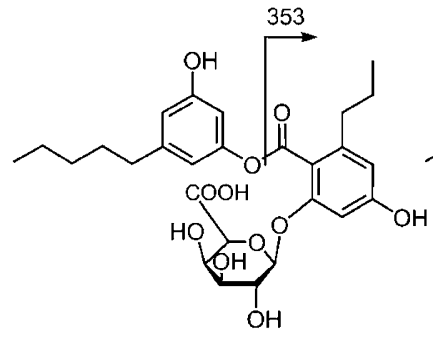

$m / z 533[\mathrm{M}-\mathrm{H}]$

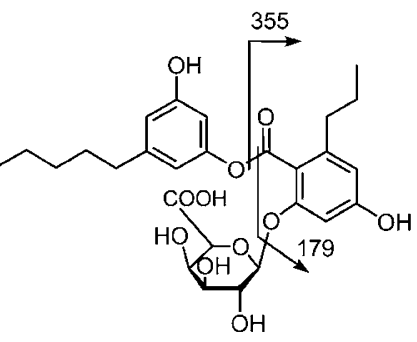

$m / z 535[\mathrm{M}+\mathrm{H}]^{+}$

Figure 5 ESIMS fragmentations of ascotricin A (1).

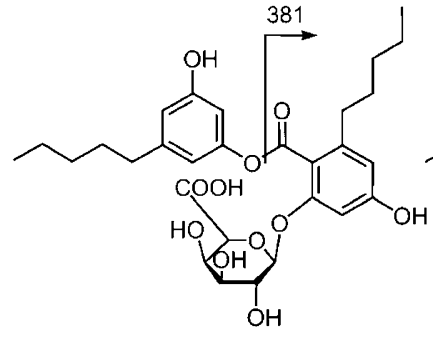

$m / z 561[\mathrm{M}-\mathrm{H}]$

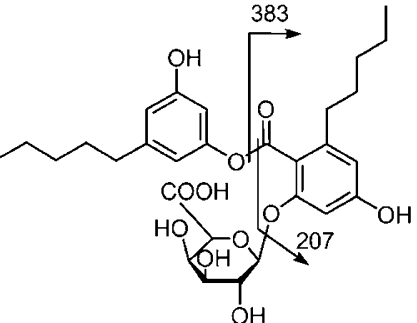

$m / z 563[\mathrm{M}+\mathrm{H}]^{+}$

Figure 6 ESIMS fragmentations of ascotricin B (2).

with the observed relative upfield chemical shift of C-3 $\left(\delta_{\mathrm{c}} 151.5\right)$ due to benzoate ester substitution, compared with phenolic C-1 $\left(\delta_{\mathrm{c}} 158.2\right)$ and $\mathrm{C}-4^{\prime}\left(\delta_{\mathrm{c}}\right.$ 159.6) and the glycosylated carbon, $\mathrm{C}-2^{\prime}\left(\delta_{\mathrm{c}} 156.3\right)$.

Although there was no direct proof of the connectivity of ring A and B obtained from the NMR experiments, the ESIMS of 1 showed a fragment ion that serves to confirm the depside linkage shown in Figure 5. A weak ion at $m / z 353$ in the negative mode ESIMS spectrum is due to a fragment ion by cleavage of the ester bond. Correspondingly, the positive mode ESIMS spectrum produced fragment ions at $\mathrm{m} / \mathrm{z} 355$ and 179 , originating from the fragmentation of the cleavage of the ester bond with or without the uronic acid moiety. Thus, the structure of 1 was determined as shown in Figure 1.

The molecular formula of 2 was determined as $\mathrm{C}_{29} \mathrm{H}_{38} \mathrm{O}_{11}$ by HRFAB-MS, indicating that it is larger than 1 by the $\mathrm{C}_{2} \mathrm{H}_{4}$ unit. The ${ }^{1} \mathrm{H}$ NMR data of 2 were similar to those of $\mathbf{1}$, except for two methylene signals. DQF COSY and HMBC experiments revealed the presence of two pentyl moieties in 2. In the HMBC spectrum, longrange correlations were observed between $\mathrm{H}-8^{\prime}$ and $\mathrm{C}-\mathrm{1}^{\prime}, \mathrm{C}-5^{\prime}$ and C- $6^{\prime}$, thus it was revealed that one pentyl moiety was connected to C- $6^{\prime}$ on the aromatic ring B in $\mathbf{2}$ instead of the propyl moiety in $\mathbf{1}$. From these results, the structure of $\mathbf{2}$ was determined as shown in Figure 1. The mass spectral data also supported the determined structure of 2 (Figure 6). These results revealed that compounds 1 and $\mathbf{2}$ were novel microbial metabolites and therefore we named them ascotricins A (1) and B (2), respectively (Figure 1).

\section{Biological activities}

Several papers have shown that Sph-1-P induced the decrease of intracellular cyclic AMP (cAMP) concentration through the receptor $\mathrm{S}_{1} \mathrm{P}_{1}$; therefore, we examined the $\mathrm{S}_{1} \mathrm{P}_{1}$ antagonist activity of ascotricins in a cAMP assay using $\mathrm{S}_{1} \mathrm{P}_{1}$-expressing cells. ${ }^{17,18}$ Ascotricins A and $B$ inhibited the cAMP concentration decrease induced by $100 \mathrm{nM}$ Sph-1-P, and the $\mathrm{IC}_{50}$ values were 8.2 and $1.8 \mu \mathrm{M}$, respectively

Table 3 Inhibitory activities of each compound in a cAMP assay using $\mathrm{S}_{1} \mathrm{P}_{1}$-expressing cells

\begin{tabular}{lc} 
Compound & IC 50 values $(\mu \mathrm{m})$ \\
\hline Ascotricin A (1) & 8.2 \\
Ascotricin B (2) & 1.8 \\
KS-501 (3) & $-{ }^{\mathrm{a}}$ \\
Aquastatin A (4) & - $^{\mathrm{b}}$ \\
\hline aNo inhibition at $17 \mu \mathrm{m}$. & \\
bNo inhibition at $15 \mu \mathrm{m}$. &
\end{tabular}

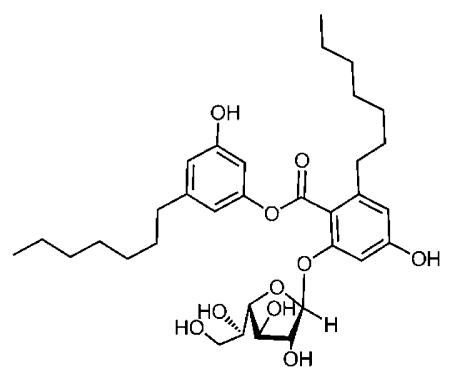

KS-501 (3)

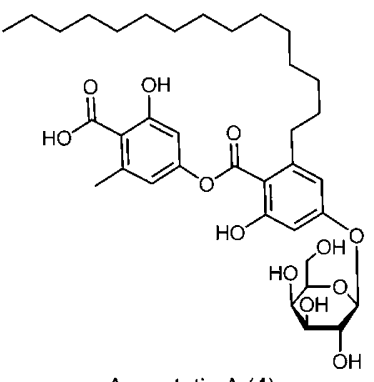

Aquastatin A (4)

Figure 7 Structures of KS-501 (3) and aquastatin A (4).

Table $4 \quad \mathrm{IC}_{50}$ values $(\mu \mathrm{m})$ of ascotricins $A(1)$ and $B(2)$ in a $\left[{ }^{33} \mathrm{P}\right]$ Sph-1-P/S1P 1 binding assay and an HUVECs migration assay

\begin{tabular}{lrc}
\hline & Binding & Migration \\
\hline Ascotricin A (1) & 120 & 94 \\
Ascotricin B (2) & 39 & 28 \\
\hline
\end{tabular}

(Table 3). Ascotricin analogs, such as KS-501 (3) and aquastatin A $(4)^{19-21}$ did not show any inhibition at 17 and $15 \mu \mathrm{M}$, respectively (Figure 7 and Table 3). Next, we checked whether ascotricins inhibited $\left[{ }^{33} \mathrm{P}\right]$ Sph-1-P binding to $\mathrm{S}_{1} \mathrm{P}_{1}$ in a receptor-binding assay. According to the results, both ascotricins $\mathrm{A}$ and $\mathrm{B}$ inhibited $\left[{ }^{33} \mathrm{P}\right] \mathrm{Sph}-1-\mathrm{P} / \mathrm{S} 1 \mathrm{P}_{1}$ binding, and the $\mathrm{IC}_{50}$ values were 120 and $39 \mu \mathrm{M}$, respectively (Table 4). Finally, to test whether ascotricins could suppress the biological effect of Sph-1-P on vascular endothelial cells, we performed a migration assay of human umbilical vein endothelial cells (HUVECs), the primary vascular endothelial cells that endogenously express $\mathrm{S}_{1} \mathrm{P}_{1}$, and the inhibition activity of ascotricins was evaluated in the assay. According to the results, ascotricins A and B suppressed HUVEC migration by $100 \mathrm{~nm}$ Sph-1-P, and the $\mathrm{IC}_{50}$ values were 94 and $28 \mu \mathrm{M}$, respectively (Table 4 ).

\section{DISCUSSION}

A. chartarum Berk. SANK 14186, Sporothrix sp. KAC-1985 and Fusarium aquaeductuum SANK 11089 are fungi that belong to a different order. Nevertheless, their products, ascotricins, KS-501 (3) (as an inhibitor of $\mathrm{Ca}^{2+}$ and calmodulin-dependent cyclic nucleotide phosphatase) and aquastatin A (4) (as an inhibitor of mammalian adenosine triphosphatase), have similar glycoside structures and resemble one another (Figure 7$)^{19-21}$. On the other hand, there are distinct structural differences between them. As KS-501 and aquastatin A were ineffective in a cAMP assay using $\mathrm{S}_{1} \mathrm{P}_{1}$-expressing cells, 
the galacturonylated depside structure of ascotricins is necessary for $\mathrm{S}_{1} \mathrm{P}_{1}$ antagonism. Therefore, ascotricins $\mathrm{A}$ and $\mathrm{B}$ are novel antagonists of $\mathrm{S}_{1} \mathrm{P}_{1}$. We also found that aranorosin, ${ }^{22}$ analogs of caloporoside ${ }^{23}$ and cinatrins ${ }^{24,25}$ had $\mathrm{S}_{1} \mathrm{P}_{1}$ antagonist activity (data not shown). All of these, including ascotricins, are amphipathic compounds and are also thought to be analogs of Sph-1-P.

Ascotricins inhibited HUVEC migration, and this indicates that ascotricins and their related $\mathrm{S}_{1} \mathrm{P}_{1}$ antagonists might have antiangiogenic activity. Ascotricins A and B would be useful tools for the elucidation of the function and role of $\mathrm{S}_{1} \mathrm{P}_{1}$ on vascular endothelial cells.

\section{METHODS}

\section{General}

Cell culture media and antibiotics were purchased from Invitrogen Japan KK (Tokyo, Japan). HUVECs were purchased from Kurabo Industries Ltd. (Osaka, Japan). Sph-1-P and sphingosine were purchased from Biomol International LP (Plymouth Meeting, PA, USA). $\left[\gamma-{ }^{33} \mathrm{P}\right]$ ATP was purchased from PerkinElmer Japan Co. Ltd. (Yokohoma, Japan). All other reagents were supplied by SigmaAldrich Japan (Tokyo, Japan) unless otherwise stated. NMR spectra were recorded on a Bruker AVANCE 500 spectrometer equipped with a Bruker Biospin cryogenic probe (Bruker Biospin, Osaka, Japan). The data set acquired for each sample consisted of $1 \mathrm{D}{ }^{1} \mathrm{H},{ }^{13} \mathrm{C}$ NMR, gs-DQF-COSY, gs-HSQC, gsHMBC and gs-HSQC-HOHAHA experiments. HR-FABMS data were recorded on a Micromass Autospec mass spectrometer (Nihon Waters KK, Tokyo, Japan). Optical rotations were measured with a JASCO DIP-370 spectropolarimeter (Jasco, Tokyo, Japan). IR spectra were obtained on a JASCO FT/ IR-8900 spectrometer. UV spectra were recorded on a Shimadzu UV-265FW spectrometer (Shimadzu Corp., Kyoto, Japan). GC/MS analysis was performed using an Agilent GC/MSD spectrometer (Agilent Technologies, Tokyo, Japan) (EI-MS detector, 5973; GC system, 6890; carrier gas, He). HPLC analysis was performed with an Agilent 1100 system with a photo diode array detector.

\section{LC/MS analyses}

LC/MS analysis of ascotricins was performed using an Agilent LC/MSD equipped with an ESI ion source and a Unison UK-C18 column $(75 \times 4.6 \mathrm{~mm}$. i.d., Imtakt Corp., Kyoto, Japan), with aqueous acetonitrile containing $10 \mathrm{~mm} \mathrm{HCOONH}_{4}$ and $0.01 \% \mathrm{HCOOH}$, with a flow rate of $1 \mathrm{ml} \mathrm{min}{ }^{-1}$. The fragmentor voltage for in-source fragmentation was $140 \mathrm{~V}$ in both the ESI-positive- and -negative-mode experiments.

\section{GC/MS analysis of ascotricin A (1) hydrolysate}

Compound 1 was treated with methanol containing $5 \% \mathrm{HCl}$ at $80^{\circ} \mathrm{C}$ for $4 \mathrm{~h}$ in a sealed ampoule and the mixture was dried in a stream of $\mathrm{N}_{2}$ gas. The residue was dissolved in pyridine, BSTFA was then added and the mixture was allowed to stand at room temperature for $5 \mathrm{~min}$. The reaction mixture was analyzed by GC/MS analysis under the following conditions: an HP-5 MS capillary column (Agilent, $0.25 \times 30 \mathrm{~mm}$ ) coated with $0.25 \mathrm{~mm}$ film thickness; the column temperature programed to rise by $5{ }^{\circ} \mathrm{C} / \mathrm{min}$ from 130 to $300^{\circ} \mathrm{C}$; and the flow rate of the He carrier gas set at $1.5 \mathrm{ml} \mathrm{min}^{-1}$.

\section{cAMP and receptor-binding assay}

The cAMP assay was performed as described earlier. ${ }^{26}$

For the receptor-binding assay, $\left[{ }^{33} \mathrm{P}\right] \mathrm{Sph}-1-\mathrm{P}$ was enzymatically synthesized from sphingosine and $\left[\gamma_{-}{ }^{33} \mathrm{P}\right]$ ATP using a recombinant murine sphingosine kinase. ${ }^{27}$ Human $\mathrm{S}_{1} \mathrm{P}_{1}$-expressing cells ${ }^{28}$ were seeded into 12 -well plates $\left(1 \times 10^{6}\right.$ cells per well) and cultured overnight. The next day, the plates were set on ice and the cells were washed thrice with $3 \mathrm{ml}$ of an ice-cold assay buffer ( $\alpha$-Minimum Essential Medium containing $100 \mathrm{U} \mathrm{ml}^{-1}$ penicillin-G sodium, $100 \mu \mathrm{g} \mathrm{ml}^{-1}$ streptomycin sulfate, $1 \mathrm{mg} \mathrm{ml}^{-1}$ fatty acid-free bovine serum albumin, $15 \mathrm{~mm} \mathrm{NaF}$ and $2 \mathrm{~mm}$ 4-deoxypyridoxine) and kept on ice for $10 \mathrm{~min}$. The buffer was exchanged for $0.49 \mathrm{ml}$ of a new one and $5 \mu \mathrm{l}$ of one of the buffers; for example, solvent, $50 \mu \mathrm{m}$ unlabeled Sph-1-P or various concentrations of ascotricin A or B solutions, was added. Then, $5 \mu \mathrm{l}$ of $50 \mathrm{~nm}$ $\left.{ }^{[33} \mathrm{P}\right]$ Sph-1-P $\left(1800 \mathrm{Ci} \mathrm{mmol}^{-1}\right)$ was supplied and the plates were left for $1 \mathrm{~h}$ on ice. The cells were washed thrice with $3 \mathrm{ml}$ of an ice-cold wash buffer $(50 \mathrm{~mm}$ Tris-HCl, $\mathrm{pH} 7.4,150 \mathrm{~mm} \mathrm{NaCl}$ and $1 \mathrm{mg} \mathrm{ml}^{-1}$ fatty acid-free bovine serum albumin) and lysed with $0.5 \mathrm{ml}$ of $1 \mathrm{~N} \mathrm{NaOH}-0.1 \%$ Triton X-100. The radioactivity of the lysate was measured using a liquid scintillation counter $(n=3)$.

\section{Migration assay}

A HUVEC migration assay was performed by the method of Takuwa et al. ${ }^{29}$ with modification. A serum-free F-12 nutrient mixture medium with or without $100 \mathrm{~nm}$ Sph-1-P was added to the lower wells of a 96-well chemotaxis chamber (Neuro Probe Inc., Gaithersburg, MD, USA), and a polycarbonate filter with $5 \mu \mathrm{m}$ pores (Neuro Probe Inc.,) was set. HUVECs were suspended into the medium without Sph-1-P. DMSO or various concentrations of ascotricin A or B were added into the HUVEC suspension and then incubated for $10 \mathrm{~min}$ at $37^{\circ} \mathrm{C}$ in $5 \% \mathrm{CO}_{2}$. Each HUVEC suspension $\left(6 \times 10^{4}\right.$ cells $)$ was loaded into the upper wells and the chamber was incubated for $4 \mathrm{~h}$ under the same conditions. The cells on the filter were fixed and stained with Diff-Quik (Sysmex, Kobe, Japan) and the number of migrated HUVECs that had passed through the filter was determined by measuring $\mathrm{OD}_{595}(n=4)$.

\section{ACKNOWLEDGEMENTS}

We thank Dr Takuwa for his instruction regarding the migration assay.

1 Stoffel, W. \& Assmann, G. Metabolism of sphingosine bases. XV. Enzymatic degradation of 4t-sphingenine 1-phosphate (sphingosine 1-phosphate) to 2t-hexadecen-1-al and ethanolamine phosphate. Hoppe. Seylers. Z. Physiol. Chem. 351, 1041-1049 (1970).

2 Goetzl, E. J. \& An, S. Diversity of cellular receptors and functions for the lysophospholipid growth factors lysophosphatidic acid and sphingosine 1-phosphate. FASEB. J. 12, 1589-1598 (1998).

3 Goetzl, E. J. et al. Mechanisms of lysolipid phosphate effects on cellular survival and proliferation. Ann. N. Y. Acad. Sci. 905, 177-187 (2000)

4 Lee, M. J. et al. Sphingosine-1-phosphate as a ligand for the G protein-coupled receptor EDG-1. Science 279, 1552-1555 (1998).

5 Kimura, $T$. et al. Sphingosine 1-phosphate stimulates proliferation and migration of human endothelial cells possibly through the lipid receptors, Edg-1 and Edg-3. Biochem. J. 348, 71-76 (2000).

6 Lee, M. J. et al. Akt-mediated phosphorylation of the G protein-coupled receptor EDG-1 is required for endothelial cell chemotaxis. Mol. Cell. 8, 693-704 (2001).

7 Krump-Konvalinkova, V. et al. Stable knock-down of the sphingosine 1-phosphate receptor $\mathrm{S}_{1} \mathrm{P}_{1}$ influences multiple functions of human endothelial cells. Arterioscler. Thromb. Vasc. Biol. 25, 546-552 (2005).

8 Liu, Y. et al. Edg-1, the G protein-coupled receptor for sphingosine-1-phosphate, is essential for vascular maturation. J. Clin. Invest. 106, 951-961 (2000).

9 Chae, S. S., Paik, J. H., Allende, M. L., Proia, R. L. \& Hla, T. Regulation of limb development by the sphingosine 1 -phosphate receptor $S 1 p_{1} / E D G-1$ occurs via the hypoxia/VEGF axis. Dev. Biol. 268, 441-447 (2004).

10 Mandala, S. et al. Alteration of lymphocyte trafficking by sphingosine-1-phosphate receptor agonists. Science 296, 346-349 (2002)

11 Brinkmann, V. et al. The immune modulator FTY720 targets sphingosine 1-phosphate receptors. J. Biol. Chem. 277, 21453-21457 (2002).

12 Sanna, M. G. et al. Sphingosine 1-phosphate (S1P) receptor subtypes $\mathrm{S}_{1} \mathrm{P}_{1}$ and $\mathrm{S}_{1} \mathrm{P}_{3}$, respectively, regulate lymphocyte recirculation and heart rate. J. Biol. Chem. 279, 13839-13848 (2004)

13 Davis, M. D., Clemens, J. J., Macdonald, T. L. \& Lynch, K. R. Sphingosine 1-phosphate analogs as receptor antagonists. J. Biol. Chem. 280, 9833-9841 (2005).

14 Sanna, M. G. et al. Enhancement of capillary leakage and restoration of lymphocyte egress by a chiral $\mathrm{S}_{1} \mathrm{P}_{1}$ antagonist in vivo. Nat. Chem. Biol. 2, 434-441 (2006).

15 Ono, Y. \& Kobayashi, T. Notes on new and noteworthy plant-inhabiting fungi from Japan (2): Griphosphaerioma zelkovicola sp. nov. with Sarcostroma anamorph isolated from bark of Zelkova serrata. Mycoscience 44, 109-114 (2003).

16 Hawksworth, D. L. A revision of genus Ascotricha Berk. Mycological Papers 126, 1-28 (1971).

17 Van Brocklyn, J. R. et al. Dual actions of sphingosine-1-phosphate: extracellular through the $\mathrm{G}_{\mathrm{i}}$-coupled receptor Edg-1 and intracellular to regulate proliferation and survival. J. Cell. Biol. 142, 229-240 (1998).

18 Okamoto, H. et al. EDG1 is a functional sphingosine-1-phosphate receptor that is linked via a $G_{i / o}$ to multiple signaling pathways, including phospholipase $C$ activation, $\mathrm{Ca}^{2+}$ mobilization, Ras-mitogen-activated protein kinase activation, and adenylate cyclase inhibition. J. Biol. Chem. 273, 27104-27110 (1998). 
19 Nakanishi, S., Ando, K., Kawamoto, I. \& Kase, H. KS-501 and KS-502, new inhibitors of $\mathrm{Ca}^{2+}$ and calmodulin-dependent cyclic-nucleotide phosphodiesterase from Sporothrix sp. J. Antibiot. 42, 1049-1055 (1989).

20 Yasuzawa, T., Saitoh, Y. \& Sano, H. Structures of KS-501 and KS-502, the new inhibitors of $\mathrm{Ca}^{2+}$ and calmodulin-dependent cyclic nucleotide phosphodiesterase. J. Antibiot. 43, 336-343 (1990).

21 Hamano, K. et al. Aquastatin A, an inhibitor of mammalian adenosine triphosphatases from Fusarium aquaeductuum. Taxonomy, fermentation, isolation, structure determination and biological properties. J. Antibiot. 46, 1648-1657 (1993).

22 Roy, K. et al. Aranorosin, a novel antibiotic from Pseudoarachniotus roseus. I. Taxonomy, fermentation, isolation, chemical and biological properties. J. Antibiot. 41, 1780-1784 (1988).

23 Weber, W., Schu, P., Anke, T., Velten, R. \& Steglich, W. Caloporoside, a new inhibitor of phospholipases C from Caloporus dichrous (Fr) Ryv. J. Antibiot. 47, 1188-1194 (1994).
24 Itazaki, H. et al. Cinatrins, a novel family of phospholipase $A_{2}$ inhibitors. I. Taxonomy and fermentation of the producting culture, isolation and structures of Cinatrins. J. Antibiot. 45, 38-49 (1992).

25 Tanaka, K., Itazaki, H. \& Yoshida, T. Cinatrins, a novel family of phospholipase $A_{2}$ inhibitors. II. Biological activities. J. Antibiot. 45, 50-55 (1992).

26 Nakamura, T. et al. Synthesis and SAR studies of a novel class of $\mathrm{S}_{1} \mathrm{P}_{1}$ receptor antagonists. Bioorg. Med. Chem. 15, 3548-3564 (2007).

27 Kohama, T. et al. Molecular cloning and functional characterization of murine sphingosine kinase. J. Biol. Chem. 273, 23722-23728 (1998).

28 Yonesu, K. et al. Involvement of sphingosine-1-phosphate and $\mathrm{S}_{1} \mathrm{P}_{1}$ in angiogenesis: Analyses using a new $\mathrm{S}_{1} \mathrm{P}_{1}$ antagonist of non-sphingosine-1-phosphate analog. Biochem. Pharmacol. 77, 1011-1020 (2009).

29 Arikawa, K. et al. Ligand-dependent inhibition of B16 melanoma cell migration and invasion via endogenous $\mathrm{S}_{1} \mathrm{P}_{2} \mathrm{G}$ protein-coupled receptor. Requirement of inhibition of cellular Rac activity. J. Biol. Chem. 278, 32841-32851 (2003). 